\title{
Pengembangan LKS IPA untuk Meningkatkan Ketrampilan Proses Sains Dan Kemampuan Berpikir Kritis Siswa SMP
}

\author{
Abas Susilo', Sri Atun ${ }^{2}$ \\ 1,2 SMP Ma'arif Gamping, Universitas Negeri Yogyakarta \\ E-mail: abas_jbg@yahoo.com¹, Atun_1210@yahoo.com²
}

\begin{abstract}
Abstrak
Penelitian ini bertujuan untuk mengungkapkan: (1) kelayakan dan (2) keefektifan LKS IPA dengan pendekatan guided inquiry untuk meningkatkan ketrampilan proses sains dan kemampuan berpikir kritis siswa SMP kelas VII. Prosedur pengembangan mengacu langkah-langkah dari Borg \& Gall yang meliputi studi pendahuluan, perencanaan, pengembangan draf, validasi dan revisi, uji coba terbatas dan revisi, uji coba lapangan dan penyempurnaan produk, dan diseminasi. Hasil penelitian adalah sebagai berikut. (1) LKS IPA dengan pendekatan guided inquiry dengan kelayakan menurut penilaian ahli nilai rata-rata sebesar 4,16 dengan kategori "Baik", dan guru serta teman sejawat nilai rata-rata $\geq 4,2$ dengan kategori "Sangat Baik". LKS IPA dengan pendekatan guided inquiry mampu meningkatkan ketrampilan proses sains, kemampuan berpikir kritis, dan hasil belajar kognitis siswa SMP kelas VII.

Kata Kunci: LKS IPA; guided inquiry; ketrampilan proses sains; kemampuan berpikir kritis; dan hasil belajar kognitif

\section{Developing a Science Worksheet to Improve the Science Process Skills and Critical Thinking Abbility of Students of junior high school}

\begin{abstract}
This research aims to reveal: (1) the appropriateness, and (2) effectineness of a science worksheet using guided inquiry approach to improve the science process skills and critical thinking ability of $7^{\text {th }}$ grade students. The developmental procedure based on the procedural model from Borg and Gall model including preliminary study, planning, developing prototype, validation and revision, preliminary field test and revision, operational field test and finishing product, and dissemination. The result of this reseach is a science worksheet using the guided inquiry approach with the appropriateness from professors' mean score of 4.16, which is in a "Good" category and from the teachers' and colleagues' mean score of $\geq 4.2$ which is in a "Very Good". category. The science worksheet using the guided inquiry approach is effective to improve the science process skills, critical thinking ability, and cognitive learning achievement of the $7^{\text {th }}$ grade students of junior high school .
\end{abstract}

Keywords: science worksheet; guided inquiry; science process skills; critical thinking ability; and cognitive learning achievement 



\section{PENDAHULUAN}

Indonesia sedang mengalami transisi kurikulum dari KTSP ke kurikulum 2013. Perubahan tersebut menyebabkan perubahan pada empat standar nasional pendidikan berupa standar isi, proses, kompetensi lulusan, dan penilaian. Kurikulum 2013 mengamanatkan pembelajaran dilaksanakan secara terpadu. Selain itu, menurut Permendiknas No. 65 Tahun 2013 tentang Standar Proses dinyatakan bahwa proses pembelajaran diarahkan dari siswa diberi tahu menjadi siswa mencari tahu secara aktif. Proses pengaktifan siswa dapat dilaksanakan dengan pendekatan inkuiri. National Research Countil (2000, p.13) menyatakan bahwa inkuiri adalah suatu aktifitas yang beraneka ragam dimana melibatkan observasi, menyampaikan pertanyaan, mempelajari buku, dan sumber informasi lainnya untuk melihat apa yang belum diketahui, merancang investigasi, memakai peralatan untuk mengumpulkan informasi, melakukan analisis, intepretasi data, merumuskan jawaban dari pertanyaan yang diajukan, melakukan eksplanasi, prediksi, dan menyampaikan hasilnya. Pembelajaran inkuiri memungkinkan siswa menemukan pengetahuannya sendiri dan menekankan pengembangan aspek kognitif, afektif, dan psikomotor secara seimbang (Sanjaya, 2009, pp.208-209).

Pembelajaran inkuiri terbagi atas beberapa jenis, salah satunya adalah guided inquiry. Martin (2006, p.223) menyatakan pendekatan guided inquiry berisi dua kegiatan utama yaitu guru berfokus pada pemberian penjelasan dan siswa berfokus pada metodologi penemuan. Guru hanya bertindak sebagai fasilitator yang dapat membantu siswa selama melaksanakan pembelajaran. Pada pembelajaran dengan guided inquiry proses identifikasi masalah berasal dari guru dan selama proses pembelajaran siswa diberikan banyak pancingan pertanyaan untuk mengarahkan pada tujuan yang akan dicapai (Wenning, 2005, p.7). Guided inquiry memiliki sintaks yang harus dipenuhi yaitu merumuskan masalah, mengajukan hipotesis, merencanakan dan melakukan eksperimen, mengumpulkan data, membuktikan hipotesis, dan mengkomunikasikan hasil (Tursinawati, 2012, p.50).

Terlepas dari pembelajaran yang harus mengaktifkan siswa, pembelajaran hendaknya membekali siswa dengan kecakapan hidup abad
21. Hal ini dimaksudkan agar siswa mampu untuk beradaptasi terhadap perkembangan informasi dan teknologi di era globalisasi ini. Salah satu kecakapan hidup abad 21 ini adalah berpikir kritis. Berpikir kritis menurut Santrock (2007, p.144) adalah berpikir secara reflektif dan produktif serta melakukan evaluasi terhadap fakta. Terdapat beberapa ciri orang berpikir kritis menurut Paul (2007, p.4) yaitu mampu memunculkan pertanyaan dan masalah, mampu mengumpulkan dan menilai informasi, mampu menyimpulkan, mempunyai keterbukaan pikiran, dan mampu berkomunikasi secara efektif.

Proses pembelajaran tidak terlepas dari bahan ajar yang digunakan oleh guru. Bahan ajar yang digunakan pada kurikulum 2013 adalah buku Kurikulum 2013. Isi buku tersebut sebenarnya dapat digunakan untuk mengaktifkan siswa, akan tetapi masih terdapat beberapa kegiatan yang menyulitkan siswa sehingga perlu bahan ajar pendamping untuk mengaktifkan siswa. Bahan ajar pendamping yang dapat dikembangkan guru adalah LKS. Depdiknas (2007, p.26) menyatakan LKS adalah lembaran yang berisi tugas yang harus dikerjakan siswa dan berisi petunjuk, langkah yang harus dilakukan untuk menyelesaikan tugas berupa teori dan praktek. Selain itu, LKS juga dapat digunakan dalam melakukan kegiatan penyelidikan atau pemecahan masalah (Trianto, 2010, p.111). Penjelasan tersebut menunjukkan bahwa LKS dapat dilaksanakan sebagai bahan ajar pendukung untuk mengaktifkan siswa. Akan tetapi LKS yang ada di lapangan belum sesuai yang diharapkan karena hanya berupa latihan soal dan ringkasan materi, sehingga belum dapat memfasilitasi siswa untuk aktif dalam pembelajaran.

Masalah lingkungan seperti pencemaran dan pemanasan global sedang menjadi perhatian bagi masyarakat tak terkecuali dunia pendidikan. Hal ini disebabkan karena dampak pencemaran dan pemanasan global sudah dirasakan dan mengganggu kelangsungan hidup manusia. Masalah ini perlu mendapatkan perhatian agar tidak berdampak semakin parah. Siswa sebagai generasi penerus hendaknya diberi pengetahuan sejak awal mengenai masalah tersebut. Hal ini dimaksudkan agar siswa ikut berperan aktif dalam menjaga alam dan membantu mengurangi dampak pencemaran dan pemanasan global.

Hasil observasi yang dilakukan di SMP N 2 Turi menunjukkan bahwa sekolah tersebut sudah menerapkan kurikulum 2013. Selanjutnya, 


\section{JEMS (Jurnal Edukasi Matematika dan Sains), 5(1), Maret 2017- 10}

Abas Susilo, Sri Atun

kegiatan pembelajaran yang dilakukan belum sepenuhnya mengaktifkan siswa (student center). Hal ini terlihat dari pembelajaran yang dilakukan dengan tanya jawab dan belum dilaksanakan dengan pendekatan ilmiah (discovery/inquiry). Fenomena ini disebabkan karena bahan ajar yang digunakan adalah buku kurikulum 2013 masih menimbulkan kesulitan siswa ketika melaksanakan kegiatannya, sehingga kegiatan yang terdapat dalam buku tersebut belum dapat dilaksanakan. Selain itu, proses pengaktifan siswa tidaklah mudah karena mereka sudah terbiasa dengan gaya belajar dimana guru sebagai subjek pembelajaran. Hal ini berakibat pada kemampuan siswa yang berkembang hanya pada aspek kognitif semata, namun aspek sikap dan ketrampilan kurang berkembang maksimal.

Ditinjau dari fasilitas pendukung pembelajaran IPA, SMP N 2 Turi memiliki satu laboratorium IPA dimana mempunyai alat yang cukup lengkap dan dilengkapi dengan LCD yang dapat digunakan guru dalam menampilkan media visual. Selain itu, ditinjau dari letak geografis SMP N 2 Turi berada pada daerah rawan bencana letusan gunung Merapi karena berada pada radius $20 \mathrm{Km}$ dari puncak dan berada di sebelah jalan alternatif antar kabupaten. Kondisi ini menyebabkan siswa dekat terhadap polusi yang terjadi karena hilir mudik kendaraan dan letusan gunung Merapi. Untuk itulah, perlu adanya perhatian atas masalah tersebut, mengingat pada erupsi Merapi 2010 yang lalu wilayah Turi diselimuti abu vulkanik yang cukup tebal sehingga mengakibatkan dampak pada lingkungan. Siswa perlu diberikan pengetahuan mengenai dampak abu vulkanik terhadap lingkungan sehingga berdasarkan pengalaman yang mereka miliki dapat mengkondisikan diri manakala terjadi erupsi gunung Merapi.

Untuk mengatasi permasalahan di atas perlu adanya inovasi yang dilakukan dalam pembelajaran IPA. Salah satunya adalah dengan mengembangkan bahan ajar pendukung berupa LKS. Pengembangan LKS sebagai bahan ajar pendukung diharapkan dapat mengaktifkan siswa dan mengubah kedudukan siswa dari objek pembelajaran menjadi subjek pembelajaran. Selain itu, LKS yang dikembangkan hendaknya menggunakan suatu pendekatan tertentu sehingga langkah pembelajaran menjadi jelas. Berdasarkan kondisi siswa yang belum terbiasa melakukan kegiatan eksperimen maka peran guru dalam memberikan bimbingan kepada siswa masih sangat dibutuhkan. Oleh sebab itu, maka pendekatan yang dirasa cocok digunakan dalam LKS adalah guided inquiry. Pendekatan guided inquiry memberikan kewenangan kapada guru untuk membimbing siswa pada proses pembelajaran. Proses pembimbingan siswa tidak dilaksanakan pada semua langkah pembelajaran, sehingga siswa diharapkan dapat mendapat pengalaman dan mengembangkan potensi yang terdapat dalam dirinya.

Pengembangan LKS IPA dengan pendekatan guided inquiry ini diharapkan dapat memfasilitasi siswa untuk belajar secara aktif dan mampu mengembangkan ketrampilan proses sains serta kemampuan berpikir kritis. Ketrampilan proses sains merupakan suatu ketrampilan untuk mengkaji fenomena alam dengan cara tertentu untuk memperoleh ilmu dan mengembangkan ilmu selanjutnya (Bundu, 2006, p.12). Katrampilan proses dapat berupa kemampuan untuk melakukan metode ilmiah dimana terdapat kemampuan mengidentifikasi pertanyaan, membuat prediksi, merancang investigasi, mencari dan analisis data, mengambil kesimpulan, dan mengkomunikasikan hasil (Liston, 2003, p.1). Pengembangan ketrampilan proses ini harus disesuaikan dengan usia siswa sehingga tidak menimbulkan beban bagi siswa dan sesuai dengan tingkat perkembangnnya.

Berpikir kritis adalah berpikir secara reflektif dan produktif yang melibatkan proses disiplin pemikiran yang aktif dan melibatkan ketrampilan konseptualisasi, menerapkan, menganalis, mensistesis, dan mengevaluasi informasi yang dikumpulkan melalui proses observasi, pengalaman, refleksi, dan penalaran sebagai hasil keyakinan dan perbuatan (Scriven $\&$ Paul, 2008). Proses untuk mendorong siswa berpikir kritis tidaklah mudah karena siswa sudah terbiasa melakukan pembelajaran yang berpusat pada guru. Untuk mengatasinya, guru dapat memberikan siswa tugas yang menuntut siswa berfokus pada isu, pertanyaan, dan persoalan, serta tidak hanya meminta siswa mengulang fakta (Santrok, 2007, p.145).

Penggunaan LKS IPA dengan pendekatan guided inquiry ini diharapkan dapat sebagai media pengaktifan siswa sehingga proses pembelajaran dapat berpusat pada siswa. Kegiatan pembelajaran yang berpusat pada siswa melalui pendekatan guided inquiry diharapkan dapat memfasilitasi pengembangan ketrampilan proses siswa dan kemampuan berpikir kritis siswa. Selain itu, LKS ini diharapkan dapat sebagai sarana untuk menyeimbangkan 
kemampuan siswa baik pada aspek sikap, kemampuan kognitif, dan ketrampilan sesuai amanat kurikulum 2013.

Tujuan penelitian dan pengembangan ini adalah untuk mengungkapkan: (1) kelayakan LKS menurut penilaian ahli, guru IPA dan teman sejawat, (2) keefektifan LKS IPA dengan pendekatan guided inquiry untuk meningkatkan ketrampilan proses sains dan kemampuan berpikir kritis siswa SMP kelas VII.

\section{METODE PENELITIAN}

Penelitian ini merupakan penelitian dan pengembangan (Research and Development) yang mengacu pada langkah-langkah model Borg n Gall (1983, p.573) yang melliputi: (1) studi pendahuluan; (2) perencanaan; pengembangan draf; (4) validasi dan revisi; (5) uji coba terbatas dan revisi; (6) uji coba lapangan dan penyempurnaan produk; serta (7) diseminasi. Validasi produk dilakukan oleh tiga dosen ahli, tiga guru IPA SMP, dan dua orang teman sejawat. Uji coba terbatas dilaksanakan di kelas VII D SMP N 2 Turi. Uji coba lapangan dilaksanakan di SMP N 2 Turi dengan kelas VII C sebagai kelas kontrol dan kelas VII B sebagai kelas eksperimen. Proses uji coba dilaksanakan pada bulan April - Mei 2014.

Teknik pengumpulan data meliputi wawancara, observasi, penilaian dengan angket, dan tes tulis. Sedangkan instrumen pengumpulan data meliputi pedoman wawancara, lembar validasi LKS, angket respon siswa, pedoman observasi keterlaksanaan RPP, pedoman observasi ketrampilan proses sains, dan soal tes ketrampilan proses sains, kemampuan berpikir kritis, dan hasil belajar kognitif. Hasil rerata validasi dan hasil observasi ketrampilan proses sains dikonversi menjadi nilai skala 5 menurut Sukardjo (2012, p.96), rerata angket respon siswa dikonversi menjadi nilai skala 4 menurut Mardhapi (2008, p.123), dan keterlaksanaan RPP ditentukan berdasarkan keterlaksanaan pembelajaran sesuai hasil observasi. Nilai gain peserta didik terhadap ketrampilan proses sains, kemampuan berpikir kritis, dan hasil belajar kognitif diperoleh dari hasil perhitungan menggunakan persamaan dari Hake (2007, p.8).

\section{HASIL DAN PEMBAHASAN}

Hasil penelitian LKS oleh validator dikonversi menjadi nilai skala 5 menurut Sukardjo (2012, p.96).
Tabel 1. Konversi Skor menjadi Nilai Skala 5

\begin{tabular}{ccc}
\hline Interval & Nilai & Kategori \\
\hline $\mathrm{X}>4,2$ & A & Sangat Baik \\
$3,4<\mathrm{X} \leq 4,2$ & B & Baik \\
$2,6<\mathrm{X} \leq 3,4$ & C & Cukup Baik \\
$1,8<\mathrm{X} \leq 2,6$ & D & Kurang Baik \\
$\mathrm{X} \leq 1,8$ & E & Sangat Kurang Baik \\
\hline
\end{tabular}

Produk LKS dilakukan penilaian kelayakan oleh dosen ahli, guru IPA, dan teman sejawat. Proses validasi ini bertujuan untuk memperoleh masukan dan saran dari segi materi, format, keterbacaan, dan pengaplikasian LKS dalam proses pembelajaran. Hasil penilaian LKS oleh validator tersaji pada tabel berikut.

Tabel 2. Hasil Penilaian LKS oleh Ahli

\begin{tabular}{ccc}
\hline Aspek & Rata-rata & Kategori \\
\hline Didaktik & 4,35 & Sangat Baik \\
Konstruksi & 3,95 & Baik \\
Teknik & 4,11 & Baik \\
Semua Aspek & 4,16 & Baik \\
\hline
\end{tabular}

Tabel 3. Hasil Penilaian LKS oleh Guru

\begin{tabular}{ccc}
\hline Aspek & Rata-rata & Kategori \\
\hline Didaktik & 4,35 & Sangat Baik \\
Konstruksi & 4,38 & Sangat Baik \\
Teknik & 4,33 & Sangat Baik \\
Semua Aspek & 4,33 & Sangat Baik
\end{tabular}

Tabel 4. Hasil Penilaian LKS oleh Teman Sejawat

\begin{tabular}{ccc}
\hline Aspek & Rata-rata & Kategori \\
\hline Didaktik & 4,72 & Sangat Baik \\
Konstruksi & 4,82 & Sangat Baik \\
Teknik & 4,59 & Sangat Baik \\
Semua Aspek & 4,72 & Sangat Baik
\end{tabular}

Tabel 2, 3, dan 4 menunjukkan bahwa hasil penilaian kelayakan LKS oleh ahli memperoleh skor 4,16 dengan kategori "Baik" dan berdasarkan penilaian guru dan teman sejawat memperoleh skor rata-rata $>4,2$ sehingga berkategori "Sangat Baik". Hal ini menunjukkan bahwa LKS hasil pengembangan layak digunakan dalam proses pembelajaran. LKS tersebut sudah memiliki kemampuan baik dalam aspek didaktik, konstruksi, maupun teknik 
sehingga memenuhi syarat sebagai LKS yang baik.
Hasil penilaian LKS oleh validator dapat dilihat pada Gambar 1.

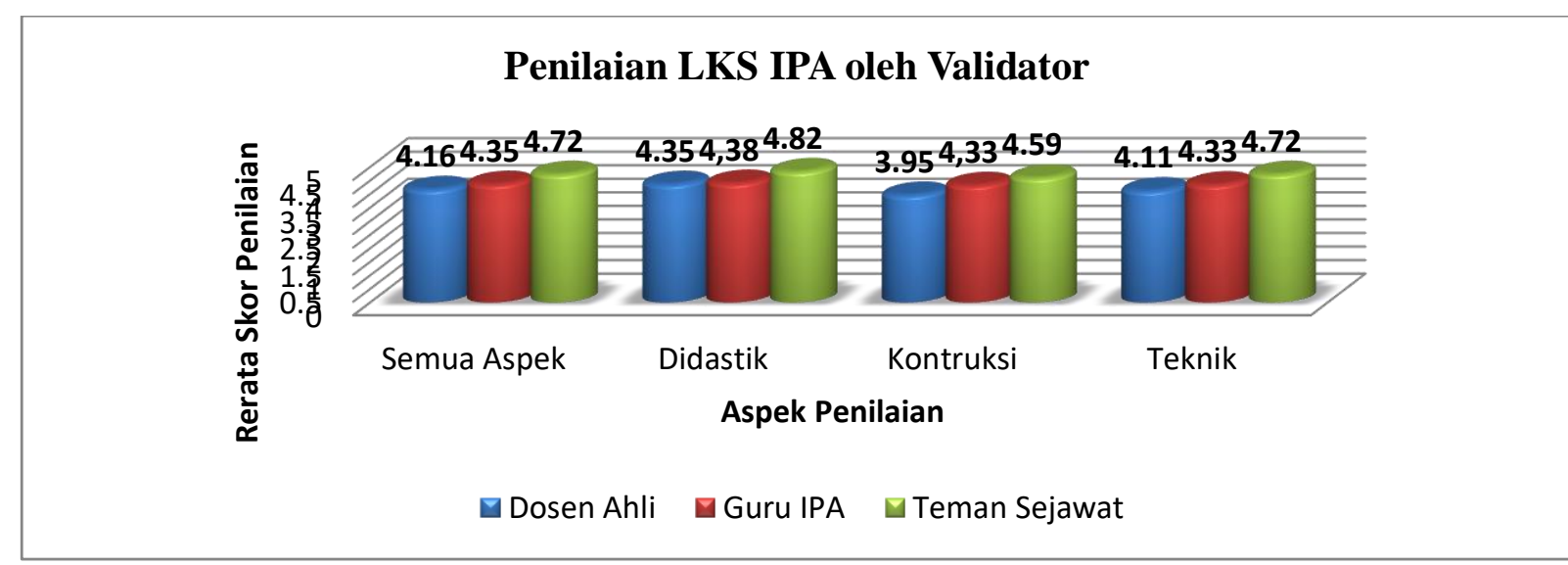

Gambar 1. Skor Validasi LKS oleh Validator

Uji coba terbatas dilaksanakan di kelas VII D SMP N 2 Turi dengan jumlah subjek 6 siswa yang didasarkan pada jenis kelamin dan kemampuan akademik. Tujuan pelaksanaan uji coba terbatas ini adalah untuk mengoperasionalkan LKS yang dikembangkan secara terbatas dan mendapatkan respon siswa. Selain itu, kendala yang didapatkan selama proses uji coba dijadikan sebagai bahan pelaksanaan revisi 2. Hasil respon siswa terhadap LKS kemudian dikonversi menjadi nilai skala 4 Mardhapi (2008, p.123).

Tabel 5. Konversi Skor menjadi Nilai Skala 4

\begin{tabular}{ccc}
\hline Interval & Nilai & Kategori \\
\hline$X \geq 3,1$ & A & Sangat Baik \\
$3,1>X \geq 2,5$ & B & Baik \\
$2,5>X \geq 1,9$ & C & Cukup Baik \\
$X<1,9$ & D & Tidak Baik \\
\hline
\end{tabular}

Tabel 6. Hasil Respon Siswa terhadap LKS pada Uji Coba Terbatas

\begin{tabular}{ccc}
\hline Aspek & Rata-rata & Kategori \\
\hline Didaktik & 3,27 & Sangat Baik \\
Konstruksi & 3,16 & Sangat Baik \\
Teknik & 3,43 & Sangat Baik \\
Semua Aspek & 3,20 & Sangat Baik \\
\hline
\end{tabular}

Berdasarkan Tabel 6. dapat dinyatakan respon siswa terhadap LKS menunjukkan nilai rata-rata > 3,1 sehingga berkategori "Sangat Baik". Hal ini berarti bahwa LKS yang dikembangkan sangat baik apabila ditinjau dari penggunaan bahasa, kosa-kata, kejelasan, tampilan, dan sebagai bahan ajar bagi siswa menurut respon siswa.

Uji coba lapangan dilaksanakan di SMP N 2 Turi Sleman dengan kelas VII C sebagai kelas kontrol dan VII B sebagai kelas eksperimen. Uji coba lapangan bertujuan untuk mengoperasionalkan LKS secara lebih luas dan mengetahui keefektifan produk dalam meningkatkan ketrampilan proses sains, kemampuan berpikir kritis dan hasil belajar kognitif siswa. Uji coba lapangan ini dilaksanakan dengan metode quasi experiment, menggunakan desain Non Equivalent Control Group Pre-Postest Design (Sugiyono, 2008, p. 116).

Tabel 7. Non Equivalent Control Group PrePostest Design

\begin{tabular}{lccc}
\hline \multicolumn{1}{c}{ Group } & Pretes & Perlakuan & Postes \\
\hline Kontrol & $\mathrm{T} 1$ & $\mathrm{Xa}$ & $\mathrm{T} 2$ \\
Eksperimen & $\mathrm{T} 1$ & $\mathrm{Xb}$ & $\mathrm{T} 2$ \\
\hline
\end{tabular}

Hasil uji coba lapangan menunjukkan prosentase keterlaksanaan LKS IPA dengan pendekatan guided inquiry sebesar 100\%. Hal ini berarti pada pelaksanaan uji coba lapangan yang dilaksanakan dalam tiga kali tatap muka, menunjukkan terpenuhinya langkah-langkah guided inquiry yang berupa merumuskan masalah, mengajukan hipotesis, merencanakan dan melakukan eksperimen, mengumpulkan data, membuktikan hipotesis, dan mengkomunikasikan hasil terlakasana secara keseluruhan. 
Selanjutnya hasil respon siswa terhadap LKS IPA dengan pendekatan guided inquiry menunjukkan hasil berikut.

Berdasarkan tabel 7. dapat dinyatakan bahwa hasil respon siswa terhadap LKS IPA dengan pendekatan guided inquiry menunjukkan kategri sangat baik. Hal ini bererti bahwa LKS yang dikembangkan sangat baik apabila ditinjau dari penggunaan bahasa, kosa-kata, kejelasan, tampilan, dan sebagai bahan ajar pendukung siswa dalam kegiatan pembelajaran.

Ketrampilan proses sains merupakan salah satu hakikat sains. Ketrampilan proses sains dapat berkembang optimal apabila siswa melakukan kegiatan eksperimen. Proses pengukuran ketrampilan proses sains dapat dilakukan melalui tes ketrampilan proses sains dan observasi ketrampilan proses sains selama pembelajaran berlangsung. Aspek ketrampilan proses siswa yang diukur menggunakan soal berupa ketrampilan observasi, mengukur, melakukan eksperimen, dan mengkomunikasikan hasil.

\section{Perbandingan Rata-rata Pretes dan Postes Ketrampilan Proses Sains Kelas Kontrol Dan Eksperimen}

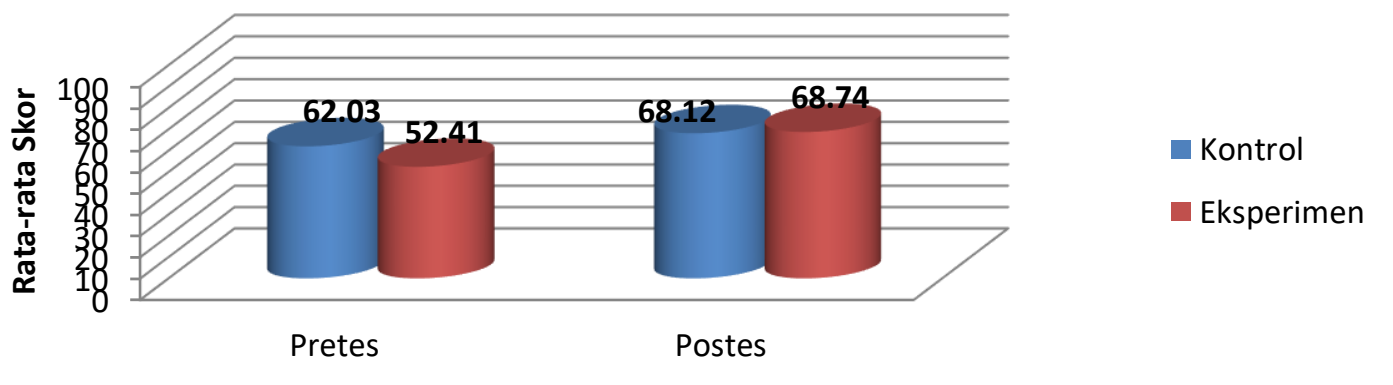

Gambar 2. Perbandingan Rata-rata Pretes dan Postes Ketrampilan Proses Sains

Berdasarkan Gambar 2. dapat dinyatakan bahwa kenaikan nilai pretes-postes siswa kelas eksperimen lebih besar apabila dibandingkan dengan kelas kontrol.. Selanjutnya, dilihat dari nilai gain ketrampilan berpikir kritis, nilai gain kelas kontrol sebesar 0,12 sedangkan kelas eksperimen sebesar 0,30. Hal ini menunjukkan bahwa penggunaan LKS hasil pengembangan memberikan dampak positif terhadap ketrampilan proses siswa. Pembelajaran yang mengaktifkan siswa melalui pendekatan guided inquiry memungkinkan siswa untuk berinteraksi dengan objek IPA dan melakukan penyelidikan terhadap fenomena IPA. Siswa mempunyai kesempatan untuk melakukan eksperimen. Kegiatan eksperimen yang dilakukan mampu menuntut siswa mengoptimalkan ketrampilan proses yang mereka miliki dan selama pelaksanaan eksperimen siswa dituntut untuk melakukan diskusi dengan teman sekelompok untuk mengatasi permasalahan yang didapat selama proses eksperimen. Pengembangan ketrampilan proses siswa hendaknya dilaksanakan dengan memberikan kesempatan siswa menggunakan ketrampilan prosesnya dalam menangani fenomena alam dengan memakai indra untuk mengumpulkan data (Herlen dalam Bundu, 2006, p.32). Pengembangan ketrampilan proses siswa dapat dilakukan secara maksimal apabila siswa terusmenerus menggunakan ketrampilan tersebut sehingga diperlukan pembiasaan.

Ketrampilan proses siswa yang didapatkan berdasarkan hasil observasi memuat ketrampilan merumuskan hipotesis, melakukan ekaperimen, melakukan pengukuran, mengamati fenomena yang tmapak, mengumpulkan fakta relevan, menuliskan data secara sistematis, berdiskusi, dan menuliskan simpulan. 
JEMS (Jurnal Edukasi Matematika dan Sains), 5(1), Maret 2017-14

Abas Susilo, Sri Atun

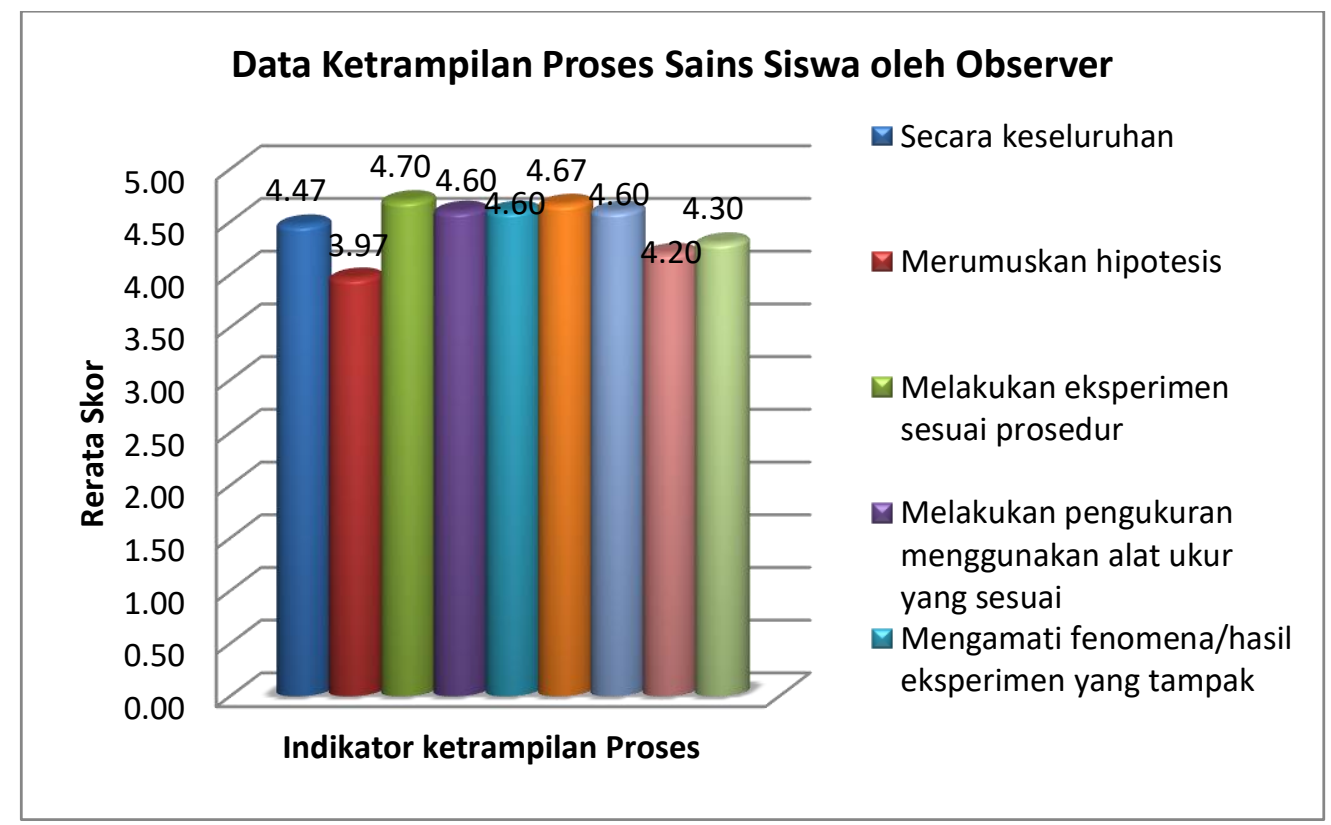

Gambar 3. Data Ketrampilan Proses oleh Observer

Berdasarkan Gambar 3. dapat dinyatakan bahwa rata-rata ketrampilan proses sains secara keseluruhan sudah sangat baik. Akan tetapi, pada aspek perumusan hipotesis dan pembuatan simpulan masih perlu ditingkatkan karena cenderung rendah jika dibandingkan dengan kemampuan lainnya. Kemampuan membuat hipotesis dan menyimpulkan memang memerlukan kemampuan menganalisis dan mencari hubungan atas fenomena yang dihadapinya. Untuk mengoptimalkan kedua aspek tersebut siswa harus senantiasa dibiasakan melakukan eksperimen.

Data kemampuan berpikir kritis siswa didapatkan dari hasil pretes dan postes kemampuan berpikir kritis siswa terhadap aspek pemfokusan pertanyaan, pengambilan keputusan, penilaian informasi yang sesuai pengamatan, dan pembuatan simpulan. Hasil pretes dan postes kemampuan berpikir kritis tersaji pada Gambar 4.

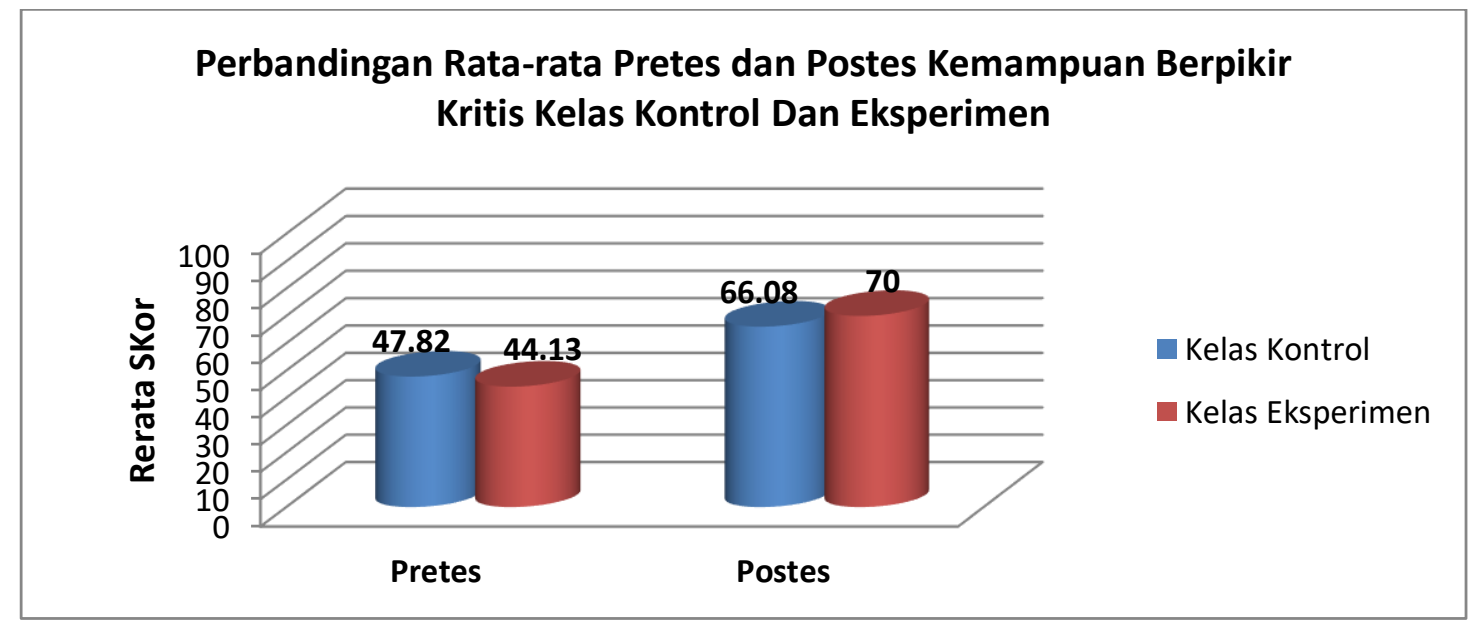

Gambar 4. Perbandingan Rata-rata Pretes dan Postes Kemampuan Berpikir Kritis Siswa

Gambar 4. menunjukkan bahwa kemampuan berpikir kritis siswa kelas eksperimen lebih tinggi apabila dibandingkan dengan kelas kontrol. Hal ini berarti LKS dengan pendekatan guided inquiry mampu untuk meningkatkan kemampuan berpikir kritis siswa. Penggunaan pendekatan guided inquiry memungkinkan siswa untuk dapat melakukan diskusi dan pemikiran terhadap fenomena yang mereka hadapi. Siswa dituntut untuk menghubungkan fenomena yang dihadapi 
dengan kemampuan dan pengalaman yang telah dimiliki siswa. Hal ini sesuai dengan tujuan pembelajaran dengan guided inquiry dimana tujuan utamanya adalah pengembangan kemampuan berpikir kritis siswa, bukan pada tujuan pembelajaran (Eggen \& Kauchak, 2012, p.201). Pengembangan kemampuan berpikir kritis perlu dilakukan secara berkelanjutan

mengingat kemampuan ini akan terasah ketika sering digunakan.

Pelaksanaan pembelajan menggunakan bahan ajar tentunya harus sesuai dengan fungsi bahan ajar yaitu untuk memudahkan atau memfasilitasi siswa mencapai tujuan pembelajaran. Untuk mengetahui ketercapaian tujuan pembelajaran maka penelitian ini melakukan pengukuran pencapaian hasil belajar menggunakan tes hasil belajar. Tingkat pencapaian kompetensi yang ditetapkan SMP N 2 Turi adalah 75. Apabila siswa dapat mencapai skor 75 , maka mereka dinyatakan tuntas terhadap kompetensi tersebut, akan tetapi apabila kurang dari 75 maka dinyatakan belum tuntas dan perlu mengikuti program remidial.

Tabel 8. Hasil Uji Normalitas

\begin{tabular}{cccc}
\hline Data & Kelas & sig & Ket \\
\hline Ketrampilan Proses & Eks & 0,104 & Normal \\
Sains (KPS) & Kontrol & 0,149 & Normal \\
Berpikir Kritis & Eks & 0,075 & Normal \\
Hasil Belajar & Kontrol & 0,061 & Normal \\
Kognitif & Kons & 0,200 & Normal \\
& & 0,106 & Normal \\
\hline
\end{tabular}

\section{Rata-Rata Skor Pretes dan Postes Hasil Belajar Kognitif Kelas} Kontrol dan Eksperimen

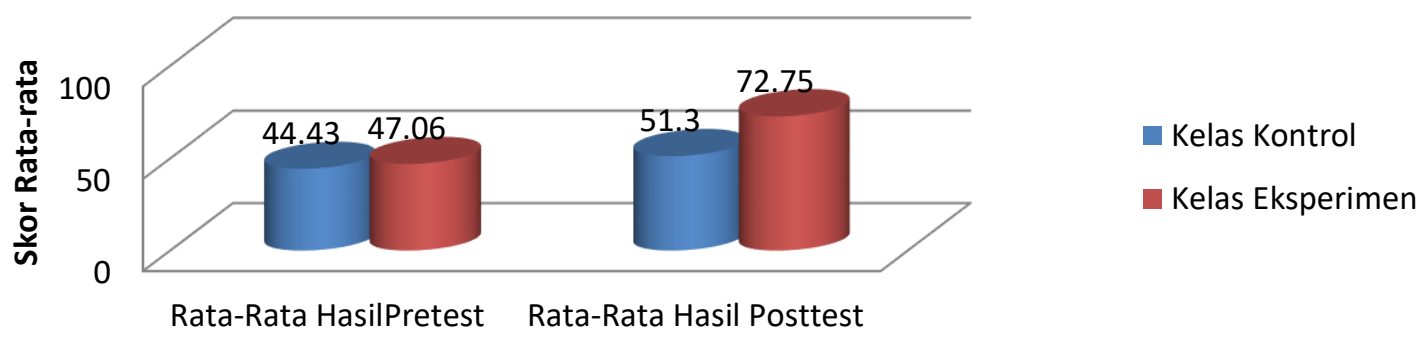

Gambar 5. Rata-rata Skor Pretes dan Postes Hasil Belajar Kognitif

Gambar 5. menunjukan skor rata-rata hasil belajar kognitif siswa pada kelas kontrol dan eksperimen. Berdasarkan data tersebut terlihat bahwa skor rata-rata hasil belajr kognitif siswa kelas eksperimen lebih tinggi apabila dibandingkan dengan kelas kontrol. Hal ini berarti bahwa LKS yang dikembangkan mampu untuk menjalankan fungsinya dalam memfasilitasi siswa mencapai tujuan pembelajaran yang akan dicapai. Data lainnya menunjukkan bahwa pada kelas kontrol terdapat satu siswa yang mencapai KKM sedangkan pada kelas eksperimen terdapat 13 siswa yang mencapai KKM. Temuan ini memperkuat bahwa penggunaan LKS dan pembelajaran menggunakan pendekatan guided inquiry mampu memberikan gambaran nyata terhadap fenomena yang mereka pelajari sehingga pengetahuan siswa menjadi lebih mendalam dan lebih luas.

Data perbedaan ketrampilan proses sains, kemampuan berpikir kritis, dan hasil belajar kognitif siswa kelas kontrol dan eksperimen diperoleh berdasarkan data yang dianalisis menggunakan uji hipotesis. Data yang digunakan merupakan nilai gain dari ketrampilan proses sains, kemampuan berpikir kritis, dan hasil belajar kognitif siswa. Tujuan dilakukan uji hipotesis ini adalah untuk mengetahui perbedaan ketrampilan proses sains, kemampuan berpikir kritis, dan hasil belajar kognitif siswa kelas eksperimen (LKS IPA dengan pendekatan guided inquiry) dan kelas kontrol (buku kurikulum 2013). Analisis data menggunakan Uji Multivariat (Manova) yang sebelumnya dilakukan uji prasarat berupa Uji Normalitas dan Uji Homogenitas. Nilai normalitas dan homogenitas data terpenuhi pada taraf signifikansi 5\% jika nilai probabilitas (sig) lebih besar dari 0,05. Uji Manova dilakukan dengan kriteria pengujian adalah $\mathrm{H}_{0}$ ditolak pada taraf signifikansi $5 \%$ yaitu jika nilai probabilitas lebih kecil dari 0,05 . 
Tabel 9. Hasil Uji Homogenitas

\begin{tabular}{lcc}
\hline \multicolumn{1}{c}{ Data } & sig & Ket \\
\hline Ketrampilan Proses & 0,148 & Homogen \\
Sains & & \\
Berpikir Kritis & 0,836 & Homogen \\
Hasil Belajar Kognitif & 0,537 & Homogen \\
\hline
\end{tabular}

Tabel 12. Hasil Uji Statistik menggunakan Manova

\begin{tabular}{llcc}
\hline \multicolumn{3}{c}{ Multivariate Tests ${ }^{\mathrm{b}}$} \\
\hline \multirow{3}{*}{ Model } & Effect & Value & \multicolumn{1}{c}{ Sig. } \\
& $\begin{array}{l}\text { Pillai's Trace } \\
\text { Wilks' }\end{array}$ & .343 & .000 \\
& Lambda & .657 & .000 \\
& $\begin{array}{l}\text { Hotelling's } \\
\text { Trace }\end{array}$ & .512 & .000 \\
& $\begin{array}{l}\text { Roy's Largest } \\
\text { Root }\end{array}$ & .512 & .000 \\
\hline
\end{tabular}

Tabel 8. dan Tabel 9. menunjukkan bahwa data ketrampilan proses sains, kemampuan berpikir kritis, dan hasil belajar kognitif berdistribuasi normal dan homogen. Selanjutnya dilakukan uji hipotesis dengan manova seperti yang tersaji pada Tabel 12. Tabel tersebut menunjukkan bahwa nilai keempat hasil signifikan dengan uji statistik kurang dari 0,05 sehingga mengakibatkan $\mathrm{H}_{0}$ ditolak pada taraf signifikansi 5\%. Berdasarkan analisis tersebut, maka dapat disimpulkan bahwa terdapat perbedaan ketrampilan proses sains, kemampuan berpikir kritis, dan hasil belajar kognitif antara siswa kelas eksperimen dengan menggunakan LKS IPA dengan pendekatan guided inquiry dan siswa kelas kontrol menggunakan buku kurikulum 2013.

\section{Keterbatasan Penelitian}

Keterbatasan penelitian dan pengembangan LKS IPA dengan pendekatan guided inquiry adalah (1) Keterbatasan waktu mengakibatkan uji coba terbatas hanya mengukur respon siswa terhadap LKS, (2) ketersediaan termometer yang dimiliki sekolah menyebabkan terjadinya perubahan pada pelaksanaan eksperimen dampak pemanasan global terhadap lingkungan, (3) Keterbatasan waktu pada uji coba lapangan menyebabkan siswa kurang memiliki kesempatan untuk menyampaikan hasil eksperimen, (4) pelaksanaan uji coba lapangan belum dilaksanakan oleh guru yang sama sehingga proses kontrol variabel kurang maksimal, (5) soal ketrampilan proses, berpikir kritis, dan hasil belajar kognitif yang berbentuk pilihan ganda, alangkah baiknya menggunakan soal uraian, dan (6) peningkatan ketrampilan proses dan kemampuan berpikir kritis membutuhkan waktu yang lama dan pembiasaan, tetapi pelaksanaan uji coba yang hanya berlangsung tiga kali tatap muka menyebabkan ketrampilan proses dan kemampuan berpikir kritisbelum berkembang maksimal.

\section{SIMPULAN DAN SARAN}

\section{SIMPULAN}

Berdasarkan rumusan masalah, tujuan penelitian, dan analisis data yang telah dilakukan, maka dapat disimpulkan: (1) LKS IPA dengan pendekatan guided inquiry mempunyai kelayakan menurut penilaian ahli nilai rata-rata sebesar 4,16 dengan kategori "Baik", dan guru serta teman sejawat nilai rata-rata $\geq 4,2$ dengan kategori "Sangat Baik", (2) LKS IPA dengan pendekatan guided inquiry mampu meningkatkan ketrampilan proses sains, kemampuan berpikir kritis, dan hasil belajar kognitis siswa SMP kelas VII.

\section{SARAN}

Saran yang dapat diberikan terkait pemanfaatan produk ini adalah: (1) LKS IPA dengan pendekatan guided inquiry dapat digunakan sebagai alternatif media pembelajaran IPA untuk siswa SMP kelas VII, (2) penggunaan LKS hasil pengembangan sebaiknya dilaksanakan dalam waktu yang memadai sehingga semua sintaks guided inquiry dapat dilaksanakan secara optimal, dan (3) pada proses penggunaan produk yang dikembangkan hendaknya guru memberikan bimbingan kepada siswa secara terbatas.

\section{DAFTAR PUSTAKA}

Borg, W.R. dan Gall, M.D. (1983). Educational reserch: an introduction. $4^{\text {th }}$. Edition. New York: logman inc. 
Bundu, P. (2006). Penilaian keterampilan proses dan sikap ilmiah dalam pembelajaran SAINS-SD. Jakarta: DEPDIKNAS.

Depdiknas. (2007). Pedoman memilih menyusun bahan ajar dan teks mata pelajaran. Jakarta: CV. Mini Jaya Abadi.

Eggen, P. \& Kauchak, D. (2012). Strategi dan model pembelajaratan mengajarkan konten dan ketrampilan berpikir. (Terjemahan Satrio Wahono) Pearson Education. (Buku asli terbit tahun 2012).

Hake, R.R. Design-based research in physics education.

Diambil dari http://www.physics.indiana. edu/ hake/DBR Physics3.pdf.

Kemendikbud. (2013). Peraturan Menteri Pendidikan dan Kebudayaan Nomor 65, tahun 2013, tentang Standar Proses

Linton, M. (2013). Science process skills in primery science. National Centre for Excellence in Mathematics and Science Teaching and Learning Vol. 4\#10 2013. p. $1-4$

Mardhapi, D. (2008). Teknik penyusunan instrumen tes dan non tes. Yogyakarta: Mitra Cendekia

Martin, D. J. (2006). Elementary science methods a constructivist approach. USA: Thomson.

National Research Countil.(2000). Inquiry and the national science standarts: a guide for theaching and learning. Washington, D.C. : National Academi Press
Paul, R dan Elder, L. (2007). The miniature guide to critical thinking concept and tools. The Foundation for Critical Thinking. p. 1-23

Sanjaya, W. (2009). Strategi pembelajaran berorientasi standar proses pendidikan. Jakarta: Kencana.

Santrock, J.W., (2007). Remaja edisi kesebelas. (Terjemahan Benedictine Widyasinta). USA: McGraw-Hill Companies. (Buku asli terbit tahun 2007).

Scriven, M. dan Paul,R. (2008). Defining critical thinking. Diambil pada tanggal 24 Juli 2013 dari http://www.criticalthinking.org/pages/defi ning-critical-thinking/766.

Sugiyono. (2008). Metode penelitian pendidikan. Bandung: Alfabeta

Sukardjo. (2012). Buku pegangan kuliah evaluasi pembelajaran IPA untuk mahasiswa S2 program studi pendidikan sains. Yogyakarta. UNY.

Trianto. (2010b). Model pembelajaran terpadu konsep, strategi, dan implementasinya dalam KTSP. Jakarta: Bumi Aksara.

Tursinawati. (2012). Penerapan pembelajaran inkuiri terbimbing untuk meningkatkan pemahaman hakikat sains siswa. Jurnal Pendidikan Serambi Ilmu Volume 11, No. 2.

Wenning, C.J. (2005). Levels of inquiry: hierarchies of pedagogical practices and inquiry processes. Journal Physict Theacer Education Online 2 (3). 